\title{
Late 1920s Film Theory and Criticism as a Test-Case for Benjamin's Generalizations on the Experiential Effects of Editing
}

\author{
Mario Slugan $^{1}$
}

Department of Film \& Television Studies, Department of German Studies, University of Warwick, Coventry, United Kingdom

This article investigates Walter Benjamin's influential generalization that the effects of cinema are akin to the hyper-stimulating experience of modernity. More specifically, I focus on his oft-cited 1935/36 claim that all editing elicits shock-like disruption. First, I propose a more detailed articulation of the experience of modernity understood as hyper-stimulation and call for distinguishing between at least two of its subsets: the experience of speed and dynamism, on the one hand, and the experience of shock/disruption, on the other. Then I turn to classical film theory of the late 1920s to demonstrate the existence of contemporary views on editing alternative to Benjamin's. For instance, whereas classical Soviet and Weimar theorists relate the experience of speed and dynamism to both Soviet and classical Hollywood style editing, they reserve the experience of shock/disruption for Soviet montage. In order to resolve the conceptual disagreement between these theorists, on the one hand, and Benjamin, on the other, I turn to late 1920s Weimar film criticism. I demonstrate that, contrary to Benjamin's generalizations about the disruptive and shock-like nature of all editing, and in line with other theorists' accounts, different editing practices were regularly distinguished by comparison to at least two distinct hyperstimulation subsets - speed and dynamism and shock-like disruption. In other words, contemporaries regularly distinguished between Soviet montage and classical Hollywood editing patterns on the basis of experiential effects alone. On the basis of contemporary reviews of city symphonies, I conclude with a proposal for distinguishing a third subsets - confusion.

Keywords: modernity thesis, hyper-stimulation, classical Hollywood editing, Soviet montage, classical film theory, historical reception in Weimar

\footnotetext{
${ }^{1}$ m.slugan.1@warwick.ac.uk
} 
The Version of Record of this manuscript has been published and is available in Early Popular Visual Culture 02 Aug 2016 www.tandfonline.com/10.1080/17460654.2016.1199322

Drawing on Georg Simmel, Siegfried Kracauer and Walter Benjamin, with Charles Baudelaire as their precursor, theorists and historians such as Stephen Kern (1983) and Wolfgang Schivelbush (1986) have argued that the advent of industrialization and urbanization in the nineteenth and early twentieth century ushered in a perceptual break characterized by experiential overload or hyper-stimulation. Starting in the 1980s a number of film scholars heralded by Tom Gunning (1986, 1989, 1991, 1993, 1994, and 1998) and Miriam Hansen (1991) have built on this work in an attempt to link silent cinema to various aspects of modernity. In an effort to describe and criticize this approach, David Bordwell (1997) coined a term - 'the modernity thesis' - soon to be adopted by the thesis' proponents and critics alike. Ben Singer (2001, 101-130), one of the thesis' most astute defenders briefly lists three of its main claims: 1) cinema is like modernity, 2) cinema is a part of modernity, and 3) cinema is a consequence of modernity. Whereas the second claim certainly holds, the first and the third have engendered a considerable ongoing debate. In this article I wish to focus on some aspects of the first claim.

As Ronald G. Waters (2008) recently noted, the most influential arguments for the claim that cinema is like modernity have revolved around descriptions of experiential effects of cinema in terms of shock and disruption. The guiding idea has been that it was in its formal principles that silent cinema elicited an immediate perceptual experience characteristic of urban modernity. In other words, the experience of 'the rapid crowding of changing images, the sharp discontinuity in the grasp of a single glance and the unexpectedness of onrushing impressions' that for Simmel (1964, 
410) characterized the turn-of-the-century city dweller's confrontation with the urban milieu was no different than the experience of silent cinema spectatorship.

Since Gunning's work, for instance, cinema up to about 1907 has been regularly construed as one of attractions - 'rapidly juxtaposed jolts of activity' with 'explosive, surprising and even disorienting temporality' $(1993,6)$. Andrea Haller has recently built on this idea to argue that the same 'mode of perception $[\ldots]$ underlay both [Simmel's reflections on modern life and the contemporary short-film cinema programme]' (2009, 114). Not only cinema of attractions but both fledgling and fully formed narrative cinema have also been described in similar terms. Both Singer (2001) and Gunning (2006) draw on shock and disruption for an account of parallel editing between 1907 and 1921 bridging transitional and classical Hollywood era to claim that 'at least one major form of narrative editing during this period [...] shows that the development of systemic narration and continuous action could also deliver a sensation of shock' (Gunning 2006, 311). In his study of Weimar cinema (1919 - 1933) Anton Kaes sees editing as a key to 'mimic[king] shock and violence on the formal level' $(2009,4)$. In his most recent monograph subtitled Film, Experience, Modernity Francesco Casetti describes all silent cinema editing as embodying modern shock-like experience: 'The cut from one shot to another gives each image the quality of shock' $(2008,4)$. Leo Charney, goes even further in describing all editing as disruptive because it is based on manipulation of parts (fragments):

Editing thus creates a collage of fragments that cannot help render the viewer's experience discontinuous. Editing's discontinuity opens up gaps and spaces throughout the action, nagging echoes of discontinuity which haunt the film's premise of continuity. (Charney 1995, 291)

The last two quotes bring us to Benjamin's famous 1935/1936 account of cinema and its translation from the collection edited by Hannah Arendt that has usually 
been taken for granted and used as inspiration for further generalizations about the experiential relationship between cinema and modernity:

[Dadaist work of art] promoted a demand for the film, the distracting element of which is also primarily tactile, being based on changes of place and focus ['der Wechsel der Schauplätze und Einstellungen'] [...] The spectator's process of association in view of these images is indeed interrupted by their constant, sudden change. This constitutes the shock effect of the film [...]. By means of its technical structure, the film has taken the physical shock effect out of the wrappers [...]. (Benjamin 1968, 238)

In what follows I wish to address the validity of Benjamin's generalization. Given that Benjamin is speaking of changes of place and focus when he is speaking of the film's technical structure, i.e. of changes of scenes and shots ('der Wechsel der Schauplätze und Einstellungen') if we are to be more faithful to the original, I shall focus on editing only and leave the questions pertaining to mostly editing-free cinema of attractions aside. ${ }^{1}$

I wish to make a case that for reasons of conceptual clarity and historical precision we need to distinguish between at least two experiential subsets within hyperstimulation. The crucial reason is that failing to discriminate among these subsets makes it impossible for the historical spectator to distinguish clearly between Soviet montage and classical Hollywood editing patterns on the basis of experiential effects alone. And this runs contrary to the fact that both classical Soviet and Weimar theorists and late1920s Weimar film critics regularly distinguished between the two. In other words, whereas in his latest revision of the modernity thesis Singer (2009) allows for discourses apart from hyper-stimulation in the discussion of the cinema-modernity complex, i.e. he recognizes that contemporaries also described cinema in neo-romantic and anti-modernist terms, my goal is to tease out contemporary distinctions within the 
discourse on hyper-stimulation in relation to editing practices. It is in this sense that I hope to contribute to recent scholarship which has taken to complicating our picture of the modernity-cinema complex from the perspective of reception studies (Daniel Biltereyst, Richard Maltby and Philippe Meers 2012; Kathryn Fuller-Seeley 2008; Frank Kessler 2009).

\section{Towards hyper-stimulation subsets: Competing theoretical accounts}

By quoting an abundance of contemporary sources compiled from material as diverse as academic journals, commentaries on neurasthenia, sensationalist press, artistic practices and art reviews Kern (1983) and Singer (1995, 2001) have demonstrated that a rich discourse on experiential overload ushered in by modernity had been well in place by the beginning of the twentieth century. ${ }^{2}$

With Gunning's remark in mind that 'there is no question that terms such as “"experience" [...] remain in need of greater precision and discussion' $(1998,267), \mathrm{I}$ wish to focus only on the immediate aspects of hyper-stimulation and discount those arising further on such as attitudes taken, emotional states developed, habits formed and behaviours indulged in. Within this framework I propose to articulate hyper-stimulation along three axes which will allow me to tease out its subsets: 1) the quantifiable properties of modern stimuli, 2) their emotional evaluation, and 3) their experiential effects articulated along two additional sub-axes. Thus, although behaviour such as thrill-seeking or stimuli avoidance, reflections on or exploitations of these stimuli, developments of blasé attitudes or neurasthenia, addictions or fears and anxieties are all part of the discourse on hyper-stimulation, I am bracketing them off in order to arrive at the vocabulary employed for the description of the immediate experience of a given modern phenomenon - viz. editing. ${ }^{3}$ 
As far as the quantifiable stimuli properties are concerned these include an increase in type, number, frequency, intensity, concentration, brevity, partiality, rate of alternation, spatial directionality, as well as rapid oscillation along these physical quantities. Emotional evaluations of these stimuli may be both positive and negative; for some these stimuli may be a source of pleasure, for others one of discomfort, and for others still a mix of both. Of crucial importance for the experiential aspect is the strain stimulus exerts. This duress ranges along a continuum from merely attention-grabbing to a sort of psychological, epistemological or even bodily failure. Moving along what might be dubbed the impact continuum, from low- to high-end, these stimuli may produce wonder, fascination, surprise, amazement, astonishment, shock, awe and finally they may even overwhelm, threaten, and make one dizzy. At the same time, on a different sub-axis, they may be perceived either as a flux of fused impressions or as an array of discrete and discontinuous sensations. It is important to note that impressions experienced as fused may produce wonder, dizziness or anything in between as much as impressions experienced as separate can.

In terms of these three axes Benjamin's experience of editing is one of shocklike disruption with mostly negative emotional valence, it ranges from mid- to high-end of the impact continuum and is based on the partial and discrete nature of stimuli (separate shots, i.e. 'fragments'). Quoting from the second version of the Artwork essay:

Dadaism attempted to produce with the means of painting (or literature) the effects which the public today seeks in film. [...] the Dadaists turned the artwork into a missile. It stabbed the viewer [zustoßen]. It gained a tactile quality. It thereby fostered the demand for film, since the distracting element in film is also primarily tactile, being based on successive changes of scenes and shots which threaten the spectator in spurts ['stoßweise auf den Beschauer eindringen']. Film has freed the physical shock effect - which Dadaism had kept wrapped, as it were, inside the moral shock effect-from this wrapping. [...] Film is the art form corresponding to 
the pronounced threat to life in which people live today. It corresponds to profound changes in the apparatus of apperception - changes that are experienced on the scale private existence by each passer-by in big-city traffic [...]. (Benjamin 1989, $380-381$, italics in the original $)^{4}$

Notice how far up the impact continuum Benjamin's vocabulary is. In Benjamin we are dealing with missiles, stabs, physical shocks, threatening bursts, and even mortal danger from being run over. It is not the most pleasant of experiences. All of this also runs afoul the notions of continuity, i.e. the smooth transitions between shots. The experience of watching a film is one of constant physical and psychological assaults on the viewer, both body and soul are under constant attack, every single edit pierces through the body of the spectator like a rocket, a bullet, or a knife, it threatens the viewer like a runaway truck, each new shot disrupts one's thought processes. In other words, for Benjamin all editing causes disruptive shock.

Such conflation of the perception of an edit with the experience of shock-like disruption, however, is absent in Benjamin's contemporaries. Rudolf Arnheim, Vsevolod Pudovkin, Lev Kuleshov, and Sergei Eisenstein all regularly oppose the experiential aspects of editing in general - parallel or otherwise - to those of Soviet montage. Consider Arnheim's Film as Art first published in Berlin in 1932 which tackles a typical shot-sequence representing a visitor ringing the bell and the maid answering the door:

It might be supposed that this lightning juggling with [interior and exterior] space would be most unpleasing. Yet everyone who goes to the movies knows that actually there is no sense of discomfort. $(1957,27)$

As we can see, Arnheim clearly perceives edits and thinks of them as fast and dynamic, but he argues that there is nothing essentially disruptive about them. Contrary 
to Benjamin, for him, the technical structure of film ('the changes of scenes and shots') does not in general give rise to any perceptual shocks. Arnheim does recognize that there are particular editing practices which may come across as disruptive: '[s]ince montage separates things that are spatially continuous and joins together things that have no inherent space-time continuity, the danger arises that the process may not be successful and that the whole may disintegrate into pieces' $(1957,91)$. But such disintegration occurs only in some cases. Crucially, Arnheim singles out Soviet-style montage as being in greatest danger of producing such disruption.

Indeed, this peril was recognized by the Soviet filmmakers themselves. In 1929, Kuleshov, for instance, writes:

When we began making our own films, constructed on this principle of montage, we were set upon with cries of: 'Have pity, you crazy futurists! You show films comprised of the tiniest segments. In the eyes of the viewer the result is utter chaos. Segments jump after each other so quickly that it is thoroughly impossible to understand the action!' We listened to this and began to think what method we could adopt to combine shots so as to avoid these abrupt shifts and flashes. (1974, $55)$

One way to eliminate these disruptions, he continues, was to conform to classical Hollywood norms such as the retention of the direction of movement: "visual leap from one side of the screen to the other [...] will produce a nervous irritation which will disturb the viewer, not giving the impression of a smooth transition. Therefore, the direction of motion [...] must coincide' (Ibid.). Whereas both Kuleshov and Arnheim see the experience of shock-like disruption primarily as a sign of editing done poorly, Eisenstein argues that it is a sine qua non for what might be called montage proper. For him this experience is inextricably bound to that of attraction, an idea which he first 
develops in 1923 in the context of theatre productions and applies to film the following year:

An attraction [...] is any aggressive aspect of the theatre, i.e. any element of it that subjects the spectator to a sensual or psychological influence, verified by experience and mathematically calculated to produce specific emotional shocks. (Eisenstein 1998b, 30)

Whereas in theatre the emotional shock is secured by what is represented onstage, in film it is editing, i.e. the relationship between the shots rather than whatever is represented in any shot on its own that is key to eliciting shock. Eisenstein is, crucially, adamant that this technique evokes substantially different experiential effects than classical editing. In 1926 he writes:

America has not understood montage as a new element. America [...] does not 'parade' the figurative aspect of its montage but shows honestly what is happening. [...] In Berlin I saw the last two reels of Griffith's 1914 film The Birth of a Nation: there is a chase (as always) and nothing formally different from more recent similar [American] scenes [...] in [the last] twelve years. (Eisenstein 1998a, 81, italics in the original)

All of this clearly demonstrates that there are contemporary views on editing which dissent from Benjamin's and which find that no matter how fast and dynamic American (parallel) editing might be, unlike Soviet montage it still comes across as continuous. The perceptual experience of an edit, in other words, is not synonymous with that of disruptive shock as Benjamin would have it. It is a 'cut' rather than shocklike disruption that is the product of the non-coincidence of two temporally adjacent images, i.e. of the 'changes of scenes and shots'. There is nothing necessarily disruptive in this discontinuity. If the next image shows a different location or subject, or if the same subject is shown from a different angle or from a different position, then we 
generally perceive only a cut. But such a cut, even if shots are extremely brief as is the case in 'American' chases or races-to-the-rescue, is still compatible with continuity as the classical theorists' quotes above show. In terms of the three axes used to describe the immediate experience of editing, classical parallel editing, then, covers the low-end of the impact-continuum never reaching Benjamin's shock-like disruption, it is predominantly evaluated in positive emotional terms, and, although it can be based on numerous rapid and partial stimuli it is ultimately perceived as a continuous array of impressions.

Having demonstrated the existence of competing theoretical accounts of editing and having provided conceptual reasons for distinguishing between hyper-stimulation subsets we can do even more. By turning to contemporary Weimar criticism we can demonstrate that actual historical spectators employed distinct hyper-stimulation subsets to describe different editing practices with consistency.

I believe that an analysis of Weimar reception is particularly apt because it is precisely Weimar, with Kracauer and Benjamin as its leading cultural commentators, which has emerged as the locus classicus for the articulation of the experience of modernity in film studies. More specifically, I focus on the silent cinema from 1926 onwards as my case study because it is safe to assume that Benjamin's generalization are based on the films he viewed in this period. ${ }^{5}$ This is so because all three versions of the Artwork essay make recurrent references to films that became available to Weimar audiences in the second half of the twenties - it is Charlie Chaplin, Mickey Mouse, and 'Russian films' that together make up most of the film examples in the essays. ${ }^{6}$ Moreover, the appearance of 'Russian films' in Weimar in 1926, i.e. films coming from the Soviet Union is also particularly convenient because it allows for an important testcase for Benjamin's generalization by way of comparing contemporary reception of 
Soviet films implementing novel editing techniques with the criticism of classical Hollywood and Weimar adventure, slapstick and action films using more conventional editing. ${ }^{7}$ Finally, this analysis can also be seen as a timely empirical corrective to recent studies like Kaes' and Casetti's which generalize about the nature of editing in Weimar cinema or build on Benjamin without scrutinizing his theories against historical accounts of spectatorship. ${ }^{8}$

\section{Hyper-stimulation subsets: The continuity of speed and dynamism, and the disruption of shock}

Starting with the experience of continuity, I wish to relate it to the classical Hollywood style in its various guises and to fast-paced parallel editing in particular. Drawing on David Bordwell, Janet Staiger, and Kristin Thompson (1985), I propose that this experience is the default one of the silent cinema of the late 1910s onwards and that if no description of experience is made in the contemporary reviews then it is safe to assume that the default experience of continuity was afforded to the spectator. References to tempo and dynamism, I submit, should also be understood to fit the experience of continuity if no invocation of disruption or confusion is made. In other words, it is undeniable that contemporaries regularly described parallel editing in terms of lightning-fast speed, heart-stopping chases, breathless pursuits, non-stop action, terrific acceleration, tempo of the times, etc. This, however, amounts to only one subset of hyper-stimulation - viz. speed and dynamism. It certainly stops short of shock and disruption on the impact continuum.

For example, the joining of spatiotemporally dislocated 'fragments' through the representational technique of parallel editing in the chariot race in Fred Niblo's Ben Hur: A Tale of Christ (1925) was perceived by contemporaries as experientially different from the joining of spatiotemporally dislocated 'fragments' through the 
representational technique of montage in the Odessa steps sequence in Eisenstein's Bronenosets Potyomkin/Battleship Potemkin (1925), both first seen in Weimar in 1926. Although both were described in terms of rapidity, intensity, fascination and thrill, only the latter had an additional trait of disruption. ${ }^{9}$ This much is corroborated by Kracauer's contemporary review of Ben Hur:

[T] he sequence of images [...] develops rhythmically [...]. The chariot race intensifies from the beginning until the end, a unified grand-scale event. Its encompassing artistic mastery can be attributed to the technique in which the total views are always alternated with lightning-fast details - the heads of the racing horses. (2004b, 265, italics in the original)

The scene for Kracauer is undeniably exciting and evokes both the experience of speed ('lightning-fast') and dynamism ('intensifies') but it stops short of eliciting any disruptive shock. The details - heads of the racing horses - are standard close-ups whose alternation with totals of the race is perfectly in line with the continuity system. Under closer analysis, it is readily apparent that all of the close-ups of the horse heads are in right profile and that they are preceded and followed by shots of chariots shot from moving cameras either parallel to the chariots or in front of them. As such, in these alternations the direction of movement (left to right and back to front) is always retained, the axis of action (between Ben Hur and his antagonist Messala) is never crossed, the matches on action and eye-line matches are consistently kept, and any given action is shown only once. In a typical alternation, with the camera in all three shots moving in parallel with the race from left to right, first in total Ben Hur in the foreground is catching up with Messala in the background, then in close-up we see the heads of Messala's horses only for the camera to pan slightly to the left and reveal the heads of Ben Hur's horses gaining even more ground, and then finally, back to an even larger total in which the two come neck to neck. In other words, no rules of the classical 
continuity system are broken. Much like for classical Weimar and Soviet film theorists, then, this type of fast and dynamic editing causes no disruptions - instead, the whole sequence comes across as rhythmical and unified.

By contrast, disruption and shock proper take place only in a subclass of editing practices in which the experience of continuity underlining the transitions between shots breaks down. Take, for instance, how shock-like disruption is articulated in Pudovkin's review of Eisenstein's Battleship Potemkin focusing on the shots of the lion statues 'rising' at the end of the Odessa Steps sequence:

Those unusual jumps of bronze and stone, suddenly interrupting the flight of clouds of smoke and the collapse of stone columns, were so stunningly unexpected in their emotional effect, they matched so perfectly the shots of the explosion that the effect on the audience was one of unprecedented force $[\ldots]$ The audience $[\ldots]$ was shaken. (Pudovkin 1988, 199)

It is only here that the vocabulary goes beyond that of Arnheim's or Kracauer's unobtrusive edits and starts partaking in Benjamin's shocking irruptions of unparalleled forcefulness. The disruption, importantly, is not about the speed of editing for that would only mean that the shots of smoke and stone columns are simply too brief. Instead, the obtrusive interruption is due to the fact that the images of lion statues have nothing to do with the preceding and following images of smoke and columns crashing down. Contrary to the close-ups of horses in Ben Hur which are clearly a part of the race, no totals in Battleship Potemkin show lions as a part of either the opera headquarters or the gateway collapsing. The three lions, moreover, are shot against an undiscernible background which makes it even more difficult to situate them on site under attack. This non-diegetic quality of the images, therefore, plays an important role in Pudovkin's account of their shock-like disruptiveness. The montage of lions, furthermore, which makes it seem as though a single lion is jumping up also come 
across as disruptive. On the one hand, the technique itself - not exactly stop-motion animation but still one effecting the impression of movement - is very unusual. It appears piecemeal and staccato rather than rhythmical and unified. On the other, the movement so produced is also disruptive insofar there is no fluidity to it. Unlike the movement of horses from Ben Hur again, here the movement comes in concentrated, discrete bursts which mirror the piercing force of explosions.

That Eisenstein employed both continuous editing and disruptive experimental montage is further recognized by another notable Weimar critic - Herbert Ihering. In it, Ihering contrasts the mutiny with bringing of Vakulnichuk's body ashore. He not only specifies the shots in the latter as 'consistent', 'peaceful' and 'gliding' implying that the ones in the former are broken apart, violent and disruptive, but also employs a number of short sentences separated either by commas or full stops to articulate the mutiny's shock-like quality:

The guard aims. Interposed hands which twitch, fingers which grope for daggers. Then the sailor Vakulinchuk breaks out. The rifles are lowered. The canvas flutters empty in the wind. The frozen mass breaks loose. The riot wins out. Only Vakulinchuk falls.

Now with the highest objective consistency and with the highest artistic wisdom peaceful, gliding shots. $(2011,208)$

The style of writing itself changes to articulate this contrast. Whereas the paragraph describing the mutiny is packed with virtually minimal subject-object sentences, the following paragraph opens with a long sentence which takes its time to develop the theme of aesthetic quality and the tranquillity across shots.

This contrasting of disruption and smoothness is in line with the fact that the mutiny shot-sequence, unlike the burial one, is laden with shots which do not conform to the continuity system. The same lowering of rifles, for instance, is presented multiple 
times. On one occasion the guards lower their weapons in a close-up only for the total to reveal that they are still up. In a four-shot sequence taking place only a couple of seconds later, the guards first start lowering their rifles, the action is continued in a high-angle shot which reveals their faces, but then in the third shot there is no match on action as the weapons are higher than they were in the previous one. The fourth shot, finally, continues from where the second shot ended rather than the third. In the case of aiming, the action is not only presented multiple times but also from inconsistent angles - on some occasions the same guards point their rifles screen left, on others screen right. The six shots (plus an intertitle) depicting the transfer of Vakulinchuk's body, by contrast, present a single action without any jump-cuts progressing continuously from right to left.

From these contemporary theoretical and critical accounts the distinction between the two proposed aspects of hyper-stimulation emerges clearly: edits as inconspicuous seams versus jarring rips, sequential arrangement of images as greased up joints versus gashes of lacerated flesh, the flow of motion across shots versus fits of discrete bursts, rhythmical alternations versus staccato irruptions, the impression of speed and acceleration versus abrupt disruption, the overall gradation of energy versus concentrated missile-strikes, the excitement of physical activity versus the pain of broken limbs, the unity of parts versus the disjointedness of broken bones. In short, the continuity of classical editing versus the disruptive shock of experimental montage.

\section{A study of late 1920s Weimar film criticism}

Let us now turn to a more comprehensive analysis of Soviet montage school films available to Weimar audiences in the period between 1926 and $1930 .{ }^{10}$ I shall discuss the reception of Stachka/Strike (1925), Mat'/Mother (1926), Konets SanktPeterburga/The End of The End of St. Petersburg (1927), Oktyabr/October (1928), and 
Potomok Chingis-Khana/Storm over Asia (1928). I shall also discuss Soviet films which nowadays do not count as those employing montage techniques but which might have been discussed in terms of Soviet montage simply in virtue of coming from the Soviet Union. In fact, regardless of their exact origin, as Benjamin's essay among many attests, these films were regularly referred to as 'Russian'.

In order to examine the distinction between Hollywood-style editing and Soviet montage I turn to popular German cinema and American films which jointly dominated the German market in the period and which were readily available to Benjamin (Thomas J. Saunders 1994, 11-12). I propose to focus on adventure and slapstick films, i.e. films which abound with what would have been perceived as fast cutting and parallel editing. What is important in this analysis is whether the editing in these films was perceived as disruptive as Benjamin theorizes. In other words, whereas Tretya meshchanskaya/Bed and Sofa (1927) and Devushka s Korobkoy/When Moscow Laughs (1927) demonstrate that not all 'Russian films' were perceived as disruptive, the reviews of adventure and slapstick films show that films modelled on fast cutting and parallel editing were also perceived as stopping short from producing the experience of disruption.

The great majority of the reviews I discuss in the following section could be read in popular dailies (Das Berliner Tageblatt, Der Berliner Börsen-Courier and Die Frankfurter Zeitung), specialized press (Der Film-Kurier, Die Lichtbild-Bühne, Die literarische Welt and Die Weltbühne), in workers' press (Rote Fahne), and books on film, most notably those by Rudolf Arnheim, Béla Balázs (2010) and Alfred Kerr (1927). Among the most notable critics of the time were Siegfried Kracauer who wrote for Frankfurter Zeitung, Ihering who contributed to Berliner Börsen-Courier, Béla Balázs, Hans Feld, and Willy Haas known for their reviews in Film-Kurier, Rudolf 
Kurtz, and Hans Wollenberg for their work in Lichtbild-Bühne, Rudolf Arnheim, Axel Eggebrecht and Hans Siemsen for their criticism in Weltbühne, and Alfred Kemény and Otto Steinecke for their engagement in Rote Fahne. ${ }^{11}$ Although the discussion of these critics' reviews makes for a good part of what follows I have also tried to give voice to other less prominent figures.

\section{The 'Russian films' and the experience of shock-like disruption}

The first Soviet montage classic to premiere in the Weimar Republic after Battleship Potemkin was Pudovkin's Mother on 24 February 1927. The reviewers immediately recognized editing as one of the most important aspects of style and discussed its experiential effects in more detail. Kracauer (2004a, 334-336), Arnheim and Haas, for instance, all single out montage of landscapes as disruptive. For Arnheim, '[t]he unity of the scene, the story of the prisoner who is rejoicing, is suddenly interrupted by something totally different [i.e., the brook and the baby]' $(1957,90)$. Haas taps into Benjamin's vocabulary even more articulately when he speaks of 'irrational, expressionist and brutal film-cutting' and describes the film's 'true vitriolic style' as 'fully rugged, chopped-up, [and] caustic' (199). He continues:

Each particular shot is extra-cranked as a hundred horse power motor, chopped-up, highly original, divine landscapes are cut-in, everything is vivaciously mixed throughout [...] it is not cutting, but chop[ping], like one chops wood. [This] expressionist film-editing [does not bring about] the restitution of the naturally gliding form of film [but] the underlining of a mechanical imperfection [...] I do not hear with my eyes anything [...] as rhythm (200, italics in the original).

Numerous montages in the film in general and those of landscapes in particular certainly lend themselves to such a description. To take Arnheim's example of the Son's rejoicing because of his planned escape, the image of his rigid body covered by shadows is abrasively cut with that of a sunlit torrent of water. The same torrent is 
shown four more times but each time the axis shifts 180-degrees producing jump-cuts (given that the torrent is slightly decentred it keeps jumping left-right). Two close ups of the Son's clenched fist and shirt covered in darkness follow. Then three shots of the brook whose surface is a flurry of sun's reflections from slightly varying positions introduces even more jump-cuts. Importantly, both the torrent and the glistening water surface are shown without any contact with land making it difficult to understand the geography of this locale. The problems with constructing coherent space continue with the image of a laughing baby shot from a low-angle against the sky which makes it impossible to determine whether the baby is near the water at all. In one of the ensuing shots something falls into the brook making a splash but it is not clear at all that the baby has thrown anything. After a repetition of a few more shots of the baby, the brook, and one close-up of the Son's eyes, the intercutting closes with the recurrence of the first shot composition and the Son sitting in his cell. Altogether nineteen shots in twenty six seconds. The contrast in the lighting across the shots, the prisoner's stiffness against the flow and glistening of water and baby's animated movements, the lack of diegetic connection between the three subject matters, the jump-cuts, and the absence of coherent spatial relations, all conspire to make editing come across as disruptive. It is only in the exceptionality of its editing, then, that Mother fits Benjamin's aggressive shock-like disruption. Other films, for Haas, do 'bring out the organic of the gliding film strip' (200).

Violent disruption also comes to the fore in the reviews of two other Sovietmontage classics - Eisenstein's Strike and October premiering in Berlin on 27 February 1927 and 3 April 1928, respectively. Ihering $(2011,207)$, for instance, talks of the visual tyranny over the world and of a 'wild disorder of improvisations' ('[e]in wirres Durcheinander von Improvisations') in Strike. Axel Eggebrecht (1927), similarly, faults 
Eisenstein for not omitting various details including the shots of streams of water from water cannons. For him, these 'often disrupt the process of the whole.' Indeed, during the almost three-minute long sequence in which the workers are doused with water cannons the directionality of movement is repeatedly broken. When water hoses are pointed screen left the streams in the ensuing medium close-ups, for example, often come from the left. Near the end of the shot-sequence there is a barrage of medium close-ups in which the direction of torrent alternates left-right with each cut although they seem to be representing a group of workers in the same place doused from only one direction. In yet another example, riot police is spraying screen up but the crowd in the following shot is running for cover screen down.

Ihering also sets the general stage for the discussion of editing in October once he describes it as 'stylistically brought out of balance' and 'shatter[ing] into restless details' $(2011,220) .{ }^{12}$ Most specifically, 'the switching between various Napoleon relations is disruptive' (220), he claims. Ihering's criticism here is also directed at the satire accomplished in this way (a 'higher' formal principle than montage), but it is also undeniable that the satire is implemented through highly atypical montages. Just to cite one example, Kerensky is standing at the top of the stairs and out of the blue comes a shot of a Napoleon statue. It is true that the same posture (arms crossed) espoused by both Kerensky and Napoleon somewhat smoothens out the transition. However, not only is the light-dark contrast of the Napoleon statue far stronger (the background is completely black and the statue predominantly white) than in the previous shot but the figure in the image jumps from far right to centre left and from a total to an American shot. Most importantly, the statue is completely non-diegetic. We can again see then how the experiential effect of disruption is grounded in the divergence from the 
classical norm. Another review of October expresses the experience best: 'the montage cutting turns into the hacking of impressions painful for the eyes' (A. K. 1928).

Descriptions of editing in 'Russian films' effecting disruption over and beyond the experience of speed and dynamism continues in the reviews of other classics of Soviet montage including Pudovkin's The End of St. Petersburg and Storm over Asia premiering in Berlin on 21 February 1928 and 12 January 1929, respectively. And again this can be stylistically accounted for in terms of various deviations from the continuity system. In the case of Storm over Asia Ihering describes the contrast between anonymous Mongolian facial expressions and their intellectually riddled European counterparts as so striking that the additional representation of their different forms of behaviour becomes overwhelming and 'borderline disruptive' (222). Kracauer adds that Pudovkin 'handles the mores and customs in such detail that they, admittedly, do damage to the consistency of the film' $(2004 \mathrm{~b}, 194) .{ }^{13}$ For instance, a part of the marketplace sequence near the beginning of the film is devoted to a local sword dance. On a number of occasions transitions between shots of the two dancers - a young and an old man - appear as jump cuts. In one variant, a frontal medium shot of the old man showing off his skills is followed by the identical camera setup of the young man doing the same but their body movements do not match across the shots and their relative placement in the frame is somewhat off (the background fence, by contrast, stays perfectly in place). The jump cut appears again once we return to the old man and then yet again when the young man is shown. A bit later the whole structure is repeated but this time across six rather than four shots. In an another version, the camera setup only shows the dancers' legs and in a barrage of five shots the legs enter the shot from opposite sides of the frame in alternation - first from the left, then from the right, and after two more alternations from the right again. In the following two shots there is no 
alternations in the directionality of movement but jump cuts remain because the movement of the legs is not allowed to progress in full within a shot and across the shots the matches on action are eliminated.

As for The End of St. Petersburg, Kracauer finds that the famous intercutting of the stock exchange and the front disrupts ('durchschlagen') the viewing because of its surface tendentiousness $(2004 \mathrm{~b}, 59)$. Just to give an example from its beginning, the sequence opens with a wealthy banker walking towards a table. A match on action as he begins to sit down bring us from a long to a medium shot but then all of a sudden a cut to an explosion somewhere on the front far removed from the office. In less than four seconds three more shots flash on the screen. It is unclear whether these four shots depict the same explosion or four different ones but in either case the violent movement of the debris is not matched across the shots and the transitions result in jump cuts. The next shot is a soldier grovelling in the mud but his exact spatial relation to the explosion is no clearer than that of the banker. It is no wonder that Ihering, similarly to Kracauer, describes the shot-sequence as a 'whipping alternation' $(2011,218)$. In all of these examples, then, we are dealing with editing strategies formally distinct and perceptually significantly further up the impact continuum than those of classical Hollywood editing.

\section{The distinction from other non-disruptive editing practices}

The writings on 'Russian films' in general appear as early as 1927 (Benjamin 2008c; Haas 1927; Kerr 1927). These writings present a relatively homogenous view of Soviet cinema so it is not impossible that the descriptions of experiences I am interested in may have been made of films which for us do not make the list of the Soviet montage greats. It also must not be forgotten that the first Soviet film to be screened in Germany after the World War I - Polikushka (Alexander Sanin, USSR, 1919) - enjoyed great success and was at the time described as a work of poetry and even as a proletarian film 
(Bulgakowa 1995, 81-83). By our standards, however, the film is mediocre at best, far from incorporating revolutionary spirit and fitting well aesthetically with Kuleshov's (1974, 46-49) dismissive account of slow-paced Russian cinema of the 1910s.

A look at the reviews of two Russian films premiering in Germany on 11 May, 1928 and 15 September, 1927 - Abram Room's Tretya meshchanskaya (Bed and Sofa, 1927) and Boris Barnet's Devushka s Korobkoy (When Moscow Laughs, 1927) - dispels any worries for the experience of disruption was noted on one occasion only. ${ }^{14}$ This happens in Feld's (1928) review of When Moscow Laughs but it is explicitly attributed to German re-editing strongly suggesting that the original was perceived as the opposite in that regard. This is further supported by Rabold in Welt am Abend and Burger in Berliner Tageblatt und Handelszeitung. Rabold (1928) talks of the 'good tempo' of direction and Burger (1928) is even more explicit when he finds Barnet's direction to be working 'without any violent aberrations.'

This result can be thought of as the editing aspect of the division Haas (1927) and Balázs (1984, 198-200) made in narrative and thematic terms when they talked of the development of 'Russian films'. Balázs' first two categories present a subdivision of Haas' category of revolutionary films (Battleship Potemkin, Strike, Mother, The End of St. Petersburg, October, and Storm over Asia). Balázs makes further subdivisions based on the absence or presence of psychological motivation for revolutionary action. This joint category, which exclusively consists of films we readily recognize as the canon of the Soviet montage films, has been shown to have been regularly perceived in terms of disruption among critics writing in Weimar Republic once editing had been referred to. Balázs' third category consists of chamber plays which are about the 'transformation of private life in the collective society' and is in line with Haas' other type of 'Russian films' concerned with the construction of new Soviet morality. It includes films 
precisely like Bed and Sofa and When Moscow Laughs, ones in which non-standard editing techniques seldom appear.

The reviews of Buster Keaton's The General (1926), Fritz Lang's Metropolis (1927) and Spione (Spies, 1928), Charlie Chaplin's The Circus (1928), Joe May’s Asphalt (1929), and the aforementioned Ben Hur (1925) show that even the most fast paced American and German films were also not perceived as disruptive. ${ }^{15}$ In other words, the distinction between even the fastest Hollywood-style editing and Soviet montage was experientially clear.

Lang, for instance, is praised for editing in both Metropolis and Spies but only in terms of speed and dynamism. In the former, Haas declares him a 'master of movement composition' $(1991,195) .{ }^{16}$ Spies, similarly, are introduced in Film-Kurier as a film that 'mirrors the tempo of the times. ${ }^{17}$ Kracauer explicitly compares Russian directors with Lang and finds him to be second to none in his command of formal techniques. The more specific comparison here has to do with the effect of the experience of tempo and dynamism, and not that of disruption: 'a terrific optical reportage [...] which shows marvellous extracts and transitions and which is cut to shape with hardly believable skill' (2004a, 62). Wollenberg, finally, speaks of 'fantastic tempo' and 'rhythmical balance' in a number of scenes including perhaps the most exciting one - 'the downright grandiose [...] train catastrophe' (1928b). The fact that he invokes no disruption fits well with the shot-sequence itself which, although undeniably fast and dynamic (eight shots in fourteen seconds), complies completely with the continuity system. With the exception of a single shot of the train driver trying to stop the locomotive (which is also in line with the norm), this is essentially a fully-frontal 180degree shot/counter-shot structure in which the locomotive rushes towards the main protagonist who sees it coming and runs for cover just as it crashes. ${ }^{18}$ Eye-line matches 
(the protagonists' stare is followed by a shot of the fast-approaching locomotive) and matches on action (just prior to impact the protagonist prepares to shoot a warning shot into the air in an American cadre, which fires immediately after a switch to a long shot) are kept. Also, the action progresses continuously without repetitions and the direction of movement is retained throughout. In the final two shots of the sequence, for example, the locomotive hurls towards the protagonists' stationary train car from background to foreground and in the moment it makes contact there is a cut followed by camera movement pushing into the screen representing the locomotive crashing into the car.

Given that in his review Wollenberg also explicitly compares Spies to May's thrillers it comes as no surprise that when he writes of Asphalt he finds that 'the rhythm of the night street [is] accomplished through an exquisitely successful montage.' In a similar vein, Fritz Walter $(1993,28)$ speaks of May's directorial virtuosity '[i]n the rhythm of shot sequences, contrasting, transitions and the correspondence of shots. ${ }^{, 19}$

Contrary to Benjamin's generalization, a canonical example of slapstick comedy - The Circus - also elicited no discussion of editing techniques in terms of shock (Arnheim 1977, 196-197; Ihering 2011, 195-197; Kracauer 2004b, 32-35; Siemsen 2012, 315-318). Finally, Arnheim's remark on another slapstick - The General - which, importantly, focuses on a sequence which combines both comedy and chase, is typical for all of these reviews: 'the breath-stopping chase with vehicles gone wild is certainly nothing new' $(1977,190) .{ }^{20}$ Arnheim essentially puts the possibility of disruption in classical fast-paced editing to rest. And indeed, throughout the train chase in The General, the trains move left to right (unless they go in reverse when they expectedly move right to left), no action is repeated, the rail as the axis of action is never crossed, matches on action and eye-line matches are kept, all fully in line with the continuity system. 


\section{Conclusion}

It is undeniable that a number of silent cinema films were perceived in terms of some aspect of hyper-stimulation by their contemporary audiences. It is one thing, however, to say that a film mirrors the tempo of the times, and another that its shots are so hacked-up that they are painful to look at. The latter is at the core of the distinction between fast-paced classical Hollywood editing and shock-like Soviet montage. In other words, Benjamin's generalizations about all editing as disruptive fly in the face of classical Soviet and Weimar theory and Weimar contemporary criticism, all of which consistently distinguished between disruptive and non-disruptive editing practices. This essay can, therefore, be understood as a call for more precision when relating the experience of hyper-stimulation to that of different editing practices.

Perhaps the most surprising finding is that, contrary to standard accounts of the film as exemplary of the whole experience of hyper-stimulation (cf. Alexander Graf 2007), even an epitome of avant-garde - Walter Ruttmann's Berlin: Die Sinfonie der Großstadt/Berlin: Symphony of a Great City which premiered on 23 September 1927 is on more than one occasion described as eliciting exactly the opposite of disruption. Haas $(1991,211)$, for instance, claims that the film is 'organically grounded on [the principle of] the gliding past of the filmstrip has on the viewer' ('organisch begründet im Vorübergleiten des Filmstreifens am Zuschaer'). Ihering puts it even more explicitly when he contrasts Edmund Meisel's score to Ruttmann's editing: 'All of the curves, all of the elegant transitions, the musicality of editing - Meisel destroys it, knocks up against it' $(2011,129)$. Given that the film is even in these reviews found to elicit confusion there appears to be place for articulating another hyper-stimulation subset. Sketched out as briefly as possible, this subset would cover an experiential domain in which quantifiable values of stimuli reach new heights producing experiences at the 
high-end of the impact continuum including both epistemological and bodily misgivings. Confusion appears to take place precisely when the discrete nature of stimuli cannot be discriminated anymore at which point stimuli morph into an inchoate flux. Film scholarship, I believe, can only gain from further articulations of different experiential aspects of various editing practices.

\section{Acknowledgements}

I would like to thank Alastair Phillips and Seán Allan for their comments on the earlier drafts of this essay.

\section{Notes on Contributors}

Mario Slugan is an Associate Fellow at the University of Warwick. His interests include interwar avant-garde, early cinema, and film theory. Some of his essays have appeared in Slavic Review, an edited volume on fiction How to Make Believe, and his latest peer-reviewed piece is forthcoming in Projections. Presently, he is preparing a monograph on the perceptual experience of montage.

\section{References}

Arnheim, Rudolf. 1957. Film as Art. Berkeley: University of California Press.

Arnheim, Rudolf. 1977. Kritiken und Aufsätze zum Film. Edited by Helmut H. Diedrichs. Frankfurt am Main: Fischer Taschenbuch Verlag.

Arnheim, Rudolf. 1995. "Sturm über Asien.” In Die ungewöhnlichen Abenteuer des Dr. Mabuse im Lande der Bolschewiki, edited by Oksana Bulgakowa, 111. Berlin: Freunde der Deutschen Kinemathek.

Balázs, Béla. 1984. Der Geist des Films: Artikel und Aufsätze 1926-1931. Vol. 2 of Schriften zum Film. Edited by Helmut H. Diederichs, Wolfgang Gersch, and Magda Nagy. Munich: Hanser. 
Balázs, Béla. 2010. Béla Balázs: Early Film Theory: Visible Man and The Spirit of Film. Edited by Erica Carter. Translated by Rodney Livingstone. New York: Berghan Books.

Bordwell, David. On the History of Film Style. Cambridge, MA: Harvard University Press, 1997.

Bordwell, David. Figures Traced in Light: On Cinematic Staging. Berkeley: University of California Press, 2005.

Benjamin, Walter. 1968. "The Work of Art in the Age of Mechanical Reproduction.” In Illuminations, edited by Hannah Arendt, 217-251. New York: Schocken Books.

Benjamin, Walter. 1989. “'Das Kunstwerk im Zeitalter seiner technischer Reproduzierbarkeit': Zweite Fassung." In Nachträge. Vol. 7 of Gesammelte Schriften, edited by Rolf Tiedemann and Hermann Schweppenhäuser, 350-385. Frankfurt am Main: Suhrkamp.

Benjamin, Walter. 2008a. "Chaplin in Retrospect." In The Work of Art in the Age of Reproducibility, and Other Writings on Media, edited by Michael W. Jennings, Brigid Doherty, and Thomas Y. Levin, translated by Rodney Livingstone, 335337. Cambridge, MA: Belknap Press of Harvard University Press.

Benjamin, Walter. 2008b. "Reply to Oscar A. H. Schmitz." In The Work of Art in the Age of Technical Reproducibility and Other Writings on Media, edited by Michael W. Jennings, Brigid Doherty, and Thomas Y. Levin, translated by Rodney Livingstone, 328-332. Cambridge, MA: Belknap Press of Harvard University Press.

Benjamin, Walter. 2008c. "On the Present Situation of Russian Film.” In The Work of Art in the Age of Technical Reproducibility and Other Writings on Media, edited by Michael W. Jennings, Brigid Doherty, and Thomas Y. Levin, translated by Rodney Livingstone, 323-327. Cambridge, MA: Belknap Press of Harvard University Press.

1975. "Bett und Sofa." In Film und revolutionäre Arbeiterbewegung in Deutschland 1918-1932: Dokumente und Materialien zur Entwicklung der Filmpolitik der 
revolutionären Arbeiterbewegung und zu den Anfängen einer sozialistischen Filmkunst in Deutschland. Vol. 1, edited by Gertrude Kühn, Karl Tümmler, and Walter Wimmer, 380-381. Berlin: Henschelverlag.

Betz, Hans-Walther. 1927. "Metropolis.” Lichtbild- Bühne, January 11.

Biltereyst, Daniel, Richard Maltby and Philippe Meers, eds. 2012. Cinema Audiences and Modernity: New Perspectives on European Cinema History. Abingdon: Routledge.

Blaß, Ernst. 1993. “Asphalt.” In Der Film der Weimarer Republik: Ein Handbuch der zeitgenössischen Kritik, edited by Gero Gandert, 29-30. Berlin: Walter de Gruyter.

Bordwell, David, Janet Staiger, and Kristin Thompson. 1985. The Classical Hollywood Cinema: Film Style and Mode of Production to 1960. New York: Columbia University Press.

Boromäus. 1975. "Das Geheimnis von "Moskau, wie es weint und lacht.” In Film und revolutionäre Arbeiterbewegung in Deutschland 1918-1932: Dokumente und Materialien zur Entwicklung der Filmpolitik der revolutionären Arbeiterbewegung und zu den Anfängen einer sozialistischen Filmkunst in Deutschland. Vol. 1, edited by Gertrude Kühn, Karl Tümmler, and Walter Wimmer, 389-392. Berlin: Henschelverlag.

Bowser, Eileen. 1994. The Transformation of Cinema, 1907-1915. Berkeley: University of California Press.

Bulgakowa, Oksana. 1995. "Russische Filme in Berlin.” In Die ungewöhnlichen Abenteuer des Dr. Mabuse im Lande der Bolschewiki, edited by Oksana Bulgakowa, 81-94. Berlin: Freunde der Deutschen Kinemathek.

Burger, Erich. 1928. "Moskau, wie es weint und lacht.” Berliner Tageblatt, May 13.

Carroll, Noël. 2001. "Modernity and the Plasticity of Perception." The Journal of Aesthetics and Art Criticism 59 (1): 11-17. doi: 10.1111/0021-8529.00002. 
Casetti, Francesco. 2008. Eye of the Century: Film, Experience, Modernity. New York: Columbia University Press.

Charney, Leo. 1995. "In a Moment: Film and the Philosophy of Modernity." In Cinema and the Invention of Modern Life, edited by Leo Charney and Vanessa R. Schwartz, 279-296. Berkeley: University of California Press.

Crary, Jonathan. 1999. Suspension of Perception: Attention, Spectacle, and Modern Culture. Cambridge, MA: MIT Press.

Cowan, Michael. 2010. "Advertising, Rhythm, and the Filmic Avant-Garde in Weimar: Guido Seeber and Julius Pinschewer's Kipho Film.” October 131: 23-50. doi: 10.1162/octo.2010.131.1.23.

1928. "Der deutsche Grossfilm auf dem Weltmarkt: Fritz Langs 'Spione' - ein deutscher Erfolg." Film-Kurier, March 23.

Eggebrecht, Axel. 1927. "Streik im Tauentzien-Palast.” Berliner Tageblatt, February 27.

Einsgruber, Heinz. 1975. "Sturm über Asien.” In Film und revolutionäre Arbeiterbewegung in Deutschland 1918-1932: Dokumente und Materialien zur Entwicklung der Filmpolitik der revolutionären Arbeiterbewegung und zu den Anfängen einer sozialistischen Filmkunst in Deutschland. Vol. 1, edited by Gertrude Kühn, Karl Tümmler, and Walter Wimmer, 397-398. Berlin: Henschelverlag.

Eisenstein, Sergei. 1998a. "Bela Forgets the Scissors.” In The Eisenstein Reader, edited and translated by Richard Taylor, 68-72. London: British Film Institute.

Eisenstein, Sergei. 1998b. "Montage of Attractions." In The Eisenstein Reader, edited and translated by Richard Taylor, 29-34. London: British Film Institute.

Feige, Max. 1927. “Der Film ‘Metropolis'.” Der Film, January 15.

Feld, Hans. 1928. "Moskau, wie es weint und lacht.” Film-Kurier, May 12. 
Fuller-Seeley, Kathryn, ed. 2008. Hollywood in the Neighborhood: Historical Case Studies of Local Moviegoing. Berkeley: University of California Press.

Gr., H. 1995. "Bett und Sofa.” In Die ungewöhnlichen Abenteuer des Dr. Mabuse im Lande der Bolschewiki, edited by Oksana Bulgakowa, 107. Berlin: Freunde der Deutschen Kinemathek.

Gunning, Tom. 1986. "The Cinema of Attraction: Early Film, its Spectator and the Avant-garde." Wide Angle 8 (3/4): 63-70.

Gunning, Tom. 1989. “An Aesthetic of Astonishment: Early Film and the (In)Credulous Spectator." Art and Text 34: 31-44.

Gunning, Tom. 1991. D. W. Griffith and the Origins of American Narrative Film: The Early Years at Biograph. Urbana: University of Illinois Press.

Gunning, Tom. 1993. “'Now You See It, Now You Don't': The Temporality of the Cinema of Attractions." Velvet Light Trap 32: 3-12.

Gunning, Tom. 1994. “"The Whole Town's Gawking: Early Cinema and the Visual Experience of Modernity." Yale Journal of Criticism 4 (2): 189-202.

Gunning, Tom. 1998. "Early American Cinema." In The Oxford Guide to Film Studies, edited by John Hill and Pamela Gibson Church, 255-271. Oxford: Oxford University Press.

Gunning, Tom. 2006. "Modernity and Cinema: A Culture of Shocks and Flows." In Cinema and Modernity, edited by Murray Pomerance, 297-315. New Brunswick, NJ: Rutgers University Press.

Graf, Alexander. 2007. "Paris - Berlin - Moscow: On the Montage Aesthetics in the City Symphony Films of the 1920s.” In Avant-garde Film, edited by Alexander Graf and Dietrich Schuenemann, 77-91. Amsterdam: Rodopi.

H., W. 1975. "Sturm über Asien.” In Film und revolutionäre Arbeiterbewegung in Deutschland 1918-1932: Dokumente und Materialien zur Entwicklung der Filmpolitik der revolutionären Arbeiterbewegung und zu den Anfängen einer 
sozialistischen Filmkunst in Deutschland. Vol. 1, edited by Gertrude Kühn, Karl Tümmler, and Walter Wimmer, 395-397. Berlin: Henschelverlag.

Haas, Willy. 1927. "Von der neuen russischen Filmkunst." Die Literarische Welt, September 23.

Haas, Willy. 1991. Der Kritiker als Mitproduzent: Texte zum Film 1920-1933. Edited by Wolfgang Jacobsen. Berlin: Edition Hentrich.

Hake, Sabine. 1993. Cinema's Third Machine: Writing on Film in Germany, 19071933. Lincoln: University of Nebraska Press.

Haller, Andrea. 2009. "Seen Through the Eyes of Simmel: The Cinema Programme as 'Modern' Experience.' In Film 1900: Technology, Perception, Culture, edited by Annemone Ligensa and Klaus Kreimeier, 113-124. Bloomington, IN: Indiana University Press.

Hansen, Miriam. 1991. Babel and Babylon: Spectatorship in American Silent Film. Cambridge, MA: Harvard University Press.

Hansen, Miriam. 2012. Cinema and Experience: Siegfried Kracauer, Walter Benjamin, and Theodor W. Adorno. Berkeley: University of California Press.

Ihering, Herbert. 1927. “Der Metropolisfilm.” Berliner Börsen-Courier, January 11.

Ihering, Herbert. 2011. Herbert Ihering: Filmkritiker. Edited by Karin HerbstMeßlinger. Munich: Edition Text + Kritik.

K., A. 1928. "10 Tage, die die Welt erschüttern.” Filmtechnik, April 14.

Kaes, Anton, ed. 1978. Kino-Debatte: Texte zum Verhältnis von Literatur und Film 1909-1929. Munich: Deutscher Taschenbuch-Verlag.

Kaes, Anton. 2009. Shell Shock Cinema: Weimar Culture and the Wounds of War. Princeton: Princeton University Press.

Keil, Charlie. 2001. Early American Cinema in Transition: Story, Style and Filmmaking, 1907-1913. Madison: University of Wisconsin Press. 
Keil, Charlie. 2004. “'To Here from Modernity': Style, Historiography and Transitional Cinema." In American Cinema's Transitional Era: Audiences, Institutions, Practices, edited by Charlie Keil and Shelley Stamp, 51-65. Berkeley: University of California Press.

Keil, Charlie. 2006. "Integrated Attractions: Style and Spectatorship in Transitional Cinema." In The Cinema of Attractions Reloaded, edited by Wanda Strauven, 193-204. Amsterdam: Amsterdam University Press.

Kemény, Alfred. 1975. “Eisenstein: 'Der Kampf um die Erde'.” In Film und revolutionäre Arbeiterbewegung in Deutschland 1918-1932: Dokumente und Materialien zur Entwicklung der Filmpolitik der revolutionären Arbeiterbewegung und zu den Anfängen einer sozialistischen Filmkunst in Deutschland. Vol. 1, edited by Gertrude Kühn, Karl Tümmler, and Walter Wimmer, 412-414. Berlin: Henschelverlag.

Kern, Stephen. 1983. The Culture of Time and Space 1880-1918. Cambridge, MA: Harvard University Press.

Kerr, Alfred. 1927. Russische Filmkunst. Berlin: Pollak.

Kessler, Frank. 2009. "Viewing Change, Changing Views: 'The 'History of Vision'Debate." In Film 1900: Technology, Perception, Culture, edited by Annemone Ligensa and Klaus Kreimeier, 23-36. Bloomington, IN: Indiana University Press.

Kracauer, Siegfried. 1995. "The Cult of Distraction.” In The Mass Ornament: Weimar Essays, edited and translated by Thomas Y. Levin. Cambridge, MA: Harvard University Press.

Kracauer, Siegfried. 2004a. Kleine Schriften zum Film 1. Vol. 6 of Werke. Edited by Inka Mülder-Bach and Ingrid Belke. Frankfurt am Main: Suhrkamp.

Kracauer, Siegfried. 2004b. Kleine Schriften zum Film 2. Vol. 6 of Werke. Edited by Inka Mülder-Bach and Ingrid Belke. Frankfurt am Main: Suhrkamp. 
Kuleshov, Lev. 1974. Kuleshov on Film: Writings. Edited and translated by Ronald Levaco. Berkeley: University of California Press.

Ligensa, Annemone. 2012. "Sensationalism and Early Cinema." In A Companion to Early Cinema, edited by André Gaudreault, Nicolas Dulac and Santiago Hidalgo, 163-182. Malden, MA: Willey-Blackwell.

Marcus, Paul E. 1993. “Asphalt.” In Der Film der Weimarer Republik: Ein Handbuch der zeitgenössischen Kritik, edited by Gero Gandert, 31-32. Berlin: Walter de Gruyter. Musser, Charles, ed. 1986. Motion Picture Catalogs by American Producers and Distributors, 1894-1908 [Microform]: A Microfilm Edition. Frederick, MD: University Publications of America.

Musser, Charles. 1991. Before the Nickelodeon: Edwin S. Porter and the Edison Manufacturing Company. Berkeley: University of California Press.

Musser, Charles. 1994a. The Emergence of Cinema: The American Screen to 1907. Berkeley: University of California Press.

Musser, Charles. 1994b. "Rethinking Early Cinema: Cinema of Attractions and Narrativity." Yale Journal of Criticism 4 (2): 203-232.

Musser, Charles. 2006. "A Cinema of Contemplation, A Cinema of Discernment: Spectatorship, Intertextuality and Attractions in the 1890s." In The Cinema of Attractions Reloaded, edited by Wanda Strauven, 159-180. Amsterdam: Amsterdam University Press.

Pudovkin, Vsevolod. 1928. Filmtechnik, Filmmanuskript und Filmregie. Translated by Leonore Kündig. Zürich: Arbe.

Pudovkin, Vsevolod. 1958. Film Technique, and Film Acting. Edited and translated by Ivor Montagu. London: Vision Press.

Pudovkin, Vsevolod. 1988. "S. M. Eisenstein (From Potemkin to October)." In The Film Factory: Russian and Soviet Cinema in Documents, edited by Richard Taylor and Ian Christie, translated by Richard Taylor. Cambridge, MA: Harvard University Press, pp. 188-200. 
Rabold, Emil. 1928. "Moskau, wie es weint und lacht.” Die Welt am Abend, May 12.

Rubiner, Frida. 1975. “Um Eisensteins Oktober-Film.” In Film und revolutionäre Arbeiterbewegung in Deutschland 1918-1932: Dokumente und Materialien zur Entwicklung der Filmpolitik der revolutionären Arbeiterbewegung und zu den Anfängen einer sozialistischen Filmkunst in Deutschland. Vol. 1, edited by Gertrude Kühn, Karl Tümmler, and Walter Wimmer, 387-389. Berlin: Henschelverlag.

Salt, Barry. 2009. Film Style and Technology: History and Analysis. 3rd Ed. London: Starword.

Saunders, Thomas J. 1994. Hollywood in Berlin: American Cinema and Weimar Germany. Berkeley: California University Press.

Schivelbusch, Wolfgang. 1986. The Railway Journey: The Industrialization of Time and Space in the $19^{\text {th }}$ Century. Berkeley: University of California Press.

von Schmidt-Pauli, Edgar. "Sturm über Asien.” In Die ungewöhnlichen Abenteuer des Dr. Mabuse im Lande der Bolschewiki, edited by Oksana Bulgakowa, 111. Berlin: Freunde der Deutschen Kinemathek, 1995.

Schmitz, Oscar A. H. 1927. "Potemkinfilm und Tendenzkunst." Die Literarische Welt, March 11.

Siemsen, Hans. 1975. "Metropolis." In Film und revolutionäre Arbeiterbewegung in Deutschland 1918-1932: Dokumente und Materialien zur Entwicklung der Filmpolitik der revolutionären Arbeiterbewegung und zu den Anfängen einer sozialistischen Filmkunst in Deutschland. Vol. 1, edited by Gertrude Kühn, Karl Tümmler, and Walter Wimmer, 187-191. Berlin: Henschelverlag.

Siemsen, Hans. 2012. Hans Siemsen - Filmkritiker. Edited by Brigitte Bruns. Munich: Edition Text + Kritik

Simmel, Georg. 1964. “The Metropolis and Mental Life.” In The Sociology of Georg Simmel, edited and translated by Kurt H. Wolff, 409-424. New York: Free Press. 
Singer, Ben. 1995. "Modernity, Hyperstimulus, and the Rise of Popular Sensationalism." In Cinema and the Invention of Modern Life, edited by Leo Charney and Vanessa R. Schwartz, 72-100. Berkeley: University of California Press.

Singer, Ben. 2001. Melodrama and Modernity. New York: Columbia University Press.

Singer, Ben. 2009. "The Ambimodernity of Early Cinema: Problems and Paradoxes in the Film-and-Modernity Discourse." In Film 1900: Technology, Perception, Culture, edited by Annemone Ligensa and Klaus Kreimeier, 37-51. Bloomington, IN: Indiana University Press.

Staiger, Janet. 1992. Interpreting Films: Studies in the Historical Reception of American Cinema. Princeton, NJ: Princeton University Press.

Steinecke, Otto. 1975. "Panzerkreuz Potemkin: Uraufführung Apollo-Friedrichstraße.” In Film und revolutionäre Arbeiterbewegung in Deutschland 1918-1932: Dokumente und Materialien zur Entwicklung der Filmpolitik der revolutionären Arbeiterbewegung und zu den Anfängen einer sozialistischen Filmkunst in Deutschland. Vol. 1, edited by Gertrude Kühn, Karl Tümmler, and Walter Wimmer, 333-36. Berlin: Henschelverlag.

Turvey, Malcolm. 2011. The Filming of Modern Life: European Avant-Garde Film of the 1920s. Cambridge, MA: MIT University Press.

Vertov, Dziga. 1984. "From Kino-Eye to Radio-Eye.” In Kino-Eye: The Writings of Dziga Vertov, edited by Annette Michelson, translated by Kevin O’Brien, 85-91. Berkeley, University of California Press.

Walter, Fritz. 1993. "Asphalt.” In Der Film der Weimarer Republik: Ein Handbuch der zeitgenössischen Kritik, edited by Gero Gandert, 28-29. Berlin: Walter de Gruyter.

Walters, Ronald G. 2008. "Conclusion: When Theory Hits the Road." In Hollywood in the Neighborhood: Historical Case Studies of Local Moviegoing, edited by Kathryn Fuller-Seeley, 250-262. Berkeley: University of California Press. 
Wollenberg, Hans. 1928a. "Moskau, wie es weint und lacht." Lichtbild-Bühne, May 12.

Wollenberg, Hans. 1928b. “Spione.” Lichtbild-Bühne, March 23.

Wollenberg, Hans. 1929. “Asphalt.” Lichtbild-Bühne, March 12.

${ }^{1}$ For criticism that cinema up to 1907 was primarily perceived in terms of shock-like attractions see Charles Musser (1994b, 2006).

${ }^{2}$ Jonathan Crary (1999) does something similar by looking at more theoretical writings.

${ }^{3}$ For such wider understanding of the experience of modernity in the writings on Wilhelmine and Weimar cinema see Sabine Hake (1993). For an even wider understanding of the experience of modernity in relation to the public sphere in Weimar see Hansen (2012).

${ }^{4} \mathrm{I}$ am focusing on the second version because it has come to be regarded as the authoritative one. Although its latest translation can be found in Benjamin (2008a) I have supplanted what I believe to be a more accurate rendering.

${ }^{5}$ Given that Benjamin's talk of 'changes in scenes and shots' does not entail a discussion of sound editing and that in the section on the actor he explicitly states that sound cinema has introduced nothing new, I turn to the reception of silent films only.

${ }^{6}$ Regarding Chaplin films, in the first version of the essay Benjamin directly cites A Woman of Paris (Chaplin, 1923) in reference to the ratio between shot and final edited material. Benjamin repeats this point in his discussion of The Circus (1928) in the only article he published on Chaplin during his lifetime (Benjamin 2008a). The two films premiered in Germany in 1926 and 1928, respectively. Finally, Mickey Mouse had its debut in Steamboat Willie (Walt Disney, 1928). For an alternative interpretation which glosses over these facts and finds that Benjamin does not have empirical film as his object (and if he does that it is the cinema of the pre-classical era rather than that of the 1920s and 1930s) see Hansen $(2012,85-87)$.

${ }^{7}$ Kracauer's 1928 essay “The Cult of Distraction" is also often drawn upon to argue for an understanding of all editing as shock-like. I, however, side with Malcolm Turvey's (2011, 168-169) argument here which claims that when Kracauer speaks of distraction (a notion regularly connected to perceptual shock) he is not speaking about editing but about the distractive quality of the theater as an environment for the screening. Therefore, any arguments about editing as shock-like based on this essay are formally invalid. As I argue below, Kracauer is in fact one of those Weimar critics who, contrary to Benjamin, does not see all editing as disruptive. 
${ }^{8}$ Michael Cowan's discussion of the importance of contemporary debates on the relationship between rhythm and urban modernity allow for a different entry point to my proposed analysis of Weimar reception. Although without discussing contemporary reviews, Cowan (2010) has, for instance, argued that Guido Seeber's forgotten avant-garde gem Kipho (1925) is better understood in terms of organic rhythmical editing than Benjamin's shocklike disruptions.

${ }^{9}$ In general, importantly, the experience of tempo and dynamism and the experience of disruption are independent of each other - they may appear separately, together or not at all.

${ }^{10}$ Despite the importance given to the implied and historical spectatorship among cinema historians I am not aware of a single systematic study of contemporary experiential effects (narrowly defined) of Soviet montage films in either English or German, whereas in the case of the introduction of various editing practices Yuri Tsivian (1994) stands as a lone exception. Tsivian's original book published in Russian does analyse reception until 1930, but the English version stops at 1920. For all their invaluable information on changes in production, distribution, exhibition, representational strategies, reception, and audiences monographs by scholars of silent cinema such as Eileen Bowser (1994), Gunning (1991), Hake (1993), Kaes (1978), Keil (2004), Musser (1991, 1994), Janet Steiger (1992), or Barry Salt (2009) are not interested in analysing the reported experiential effects accompanying the introduction of new editing practices on such a fine grained level as Tsivian is.

${ }^{11}$ Where available and for the sake of convenience I cite the collections of essays where the reviews in question may be found. All of the translations of bibliography cited in German are mine. Where available I have tried to give English references.

${ }^{12}$ For a sample of reviews see Kracauer (2004b, 35-37), Frida Rubiner (1975), and Hans Siemsen, (2012, 320-324).

${ }^{13}$ For a sample of reviews see Arnheim (1995), Edgar von Schmidt-Pauli (1995), W. H. (1975), and Heinz Einsgruber (1975).

${ }^{14}$ For a sample of reviews of Bed and Sofa see Haas (1991, 219), "Bett und Sofa" (1995), and H. Gr. (1975). For a sample of reviews of When Moscow Laughs see See Boromäus (1975), Erich Burger (1928), Hans Feld (1928), Emil Rabold (1928), and Hans Wollenberg (1928a).

${ }^{15}$ The General, Metropolis, The Circus, Spies, and Asphalt premiered in Berlin on 4 April 1927, 10 January 1927, 7 February 1928, 22 March 1928, and 11 March 1929, respectively.

${ }^{16}$ For a sample of reviews of Metropolis see Arnheim (1977, 184-186), Hans-Walther Betz (1927), Max Feige (1927), Ihering (1927), and Siemsen (1975). 
${ }^{17}$ For a sample of reviews see Arnheim (1977, 202-204), Kracauer (2004b, 62-63), and Wollenberg (1928b).

${ }^{18}$ The 180-degree shot/counter-shots were, unlike today, typical in the 1910s and 1920s.

${ }^{19}$ For a sample of other reviews see Ernst Blaß (1993), Kracauer (2004b, 235-236), and Paul E. Marcus (1993).

${ }^{20}$ For a sample of reviews see Haas (1991, 202-203), Ihering (2011, 210-211), Kracauer (2004b, 328-330), and Siemsen (2012, 302-304). 